\title{
Amerikan Dış Politikasında Bir Süreklilik Unsuru: Liberal Değerlerin Yayılması ve Savunulması
}

\author{
Muhammet Faruk ÇAKIR*
}

Polis Akademisi

\section{Öz}

Liberal değerlerin yayılması ve savunulması, Amerikan dış politikasında süreklilik unsurlarından birisidir. Bu makalede ABD'nin geliştirdiği ve izlediği değerlere dayanan dıș politikanın beș özelliği incelenmiștir. Birincisi, Amerikan karar vericileri, değerlere dayanan dış politikayı hem ABD’nin hem de insanlığın yararını gözeterek izlediklerini iddia etmişlerdir. İkincisi, karar vericiler, değerleri gerçekleştirmek adına izlenen siyasalar vasıtasıyla çoğu zaman kısa dönem Amerikan çıkarları elde edilebilmişlerdir. Üçüncüsü, değerler siyaseti izlerken benimsedikleri yöntem ve araçları, çoğu zaman Amerikan çlkarlarına öncelik vererek belirlemișlerdir. Dördüncüsü, ciddi maliyetlerle karşılaştıklarında, değerlere dayanan siyasaları gözden geçirmişlerdir. Sonuncusu, değerlere dayanan dış politika, Amerikan siyasal kültürü ile uyumludur. Bu makalede, söz konusu beș özellik dolayısıyla ABD’nin izlediği değerlere dayanan dış politikanın kendine özgü olduğu ve değerlere dayanan dış politikanın sürekliliğinin de bu beş özellik ışı̆̆ında anlaşılabileceği ileri sürülmüştür. Amerikan iç siyasetinde ve dünya siyasetinde ABD’yi daha farklı davranmaya zorlayacak köklü değişiklikler meydana gelmediği müddetçe, ABD’nin değerlere dayanan dış politika anlayışı ve pratiğinde büyük bir değişim yaşanmayacağı beklenebilir.

\section{Anahtar Kelimeler}

Değerlere Dayanan Dış Politika, Liberal Değerler, Amerikan Çıkarları, Amerikan Siyasal Kültürü, Liberalizm ve Dış Politika

* Dr. Öğretim Üyesi, Polis Akademisi, Güvenlik Bilimleri Enstitüsü, mfcakir111@yahoo.com.tr, 


\title{
An Element of Continuity in American Foreign Policy: The Spread and Defense of Liberal Values
}

\begin{abstract}
The spread and defense of liberal values are one of the main elements of American foreign policy. The five features of value-based foreign policy that the United States developed and implemented are analyzed in this study. First, American decision-makers have claimed that the value-based foreign policy is beneficial for both the United States and humanity. Second, most of the time, they addressed short-term American interests by invoking values in foreign policy. Third, while carrying out policies inspired by values, they determined the methods and tools in a way that puts American interests first. Forth, they made revisions in them when they faced with serious costs. Lastly, pursuing value-based foreign policy is inspired by American political culture. This article claims that these features have made the value-based foreign policy unique to the United States. They have also contributed greatly to its constant application. Unless radical changes occur in American domestic policy and world politics, a great shift is unlikely in American conceptualization and practice of value-based foreign policy.
\end{abstract}

\section{Keywords}

Value-Based Foreign Policy, Liberal Values, American Interests, American Political Culture, Liberalism And Foreign Policy

\section{Extended Abstract}

The United States is the first country in the world where political, economic, and judicial systems are based on liberal values. Just after the American declaration of independence in 1776, the Americans began debating on whether the U.S. should spread the country's values of liberty, democracy, and political tolerance through its foreign policy. Longer than a century following its establishment, the U.S. pursued the policy of isolationism. During this period, Americans envisaged spreading liberal (American) values by making their country as an exemplar of democracy, a model for others to emulate. The administration of Woodrow Wilson abandoned the policy of isolationism when the U.S. entered World War I in 1917 and redefined the terms of American engagement in world politics. Wilson adopted the spread of democracy and the transformation of world politics according to liberal values as the goals of American foreign policy. The U.S. returned to isolationism for a while after Wilson. However, with American entrance into World War II in 1941, the policy of isolationism was abandoned once for all. Since then, the spread and defense of liberal values have been one of the core elements of the declared foreign policy of the United States.

This article is an attempt to better understand the place of liberal values in American foreign policy. It assumes that five features of value-based foreign policy come to the fore. They make the value-based foreign policy of the United States unique to this country. They also provide the underlying reasons why the spread and defense of liberal values have become an element of continuity in foreign policy. 
The first of the features is that American decision-makers have claimed that they defended liberal values for the benefit of both the U.S. and humanity. They thought so because they saw liberal values as universal values and predicted that these values could form the basis of peace and prosperity worldwide, as they provided the foundation of social peace and prosperity in the United States. The belief that American decision-makers act for the benefit of humanity provided them with a mission and also motivated them. Inspired by this idea, various American administrations included in their foreign policy agenda the goals of transformation of the international system and/ or increasing the number of countries governed by liberal democracy. The transformation of the system was given priority at the times when maintaining peace in the world was considered much more important than spreading democracy. However, the general trend of post-Cold War administrations has been to emphasize the link between the spread of democracy and security and prosperity in both the U.S. and the world as a whole.

The second feature is the realization of short-term American interests, most of the time, by invoking values in foreign policy despite the rhetoric of values implied that the U.S. would seek its interest through the realization of the common good. In other words, American administrations have often tried to address the difficulties faced by the United States in the economic, political, and security fields with the same policies that they follow to realize the values. For example, Wilson tried to prevent the spread of Bolshevik ideas with his idealistic rhetoric. W. Bush, on the other hand, saw the spread of democracy in the Middle East as a tool to deal with both al-Qaeda-inspired terrorism and authoritarianism. Thus, it can be said that policies that are pursued to achieve idealist goals also served to short-term American economic, political, and strategic interests. This aspect of idealist policies has also contributed to the endurance of value-based foreign policy.

Third, while carrying out value-based foreign policy, American policy makers choose the methods and tools in a way that puts short-term American interests first. As short-term American interests vary across time and space, so do the strategies followed and the means used by the American administrations while realizing the value-based objectives. For example, for the spread of democracy, different choices have been made, ranging from the policy of refraining from intervention to the use of military force. Accordingly, while some American governments paid attention to cooperation with other democracies and compliance with international legal norms, others did not. Choosing strategies and means according to the circumstances has reduced the risks of pursuing value-based policies. For this reason, it contributes to the endurance of the goals in American foreign policy that aim to realize liberal values.

The fourth feature of value-based foreign policy regards the cost of implementing such policies. Some of the costs (such as loss of public support for a 
specific policy, economic costs, human costs) arise at the national level. Some of them are produced by transnational factors such as violation of international law, damage to relations with allies, undesirable developments in the target state (increased risk of conflict, undesirable leaders winning elections, wasted investments, etc.). American administrations, when faced with such costs (i.e., when American interests suffer), could avoid making the choices required by the values policy, review an ongoing policy, or make a comprehensive policy change. All of these reduce the risks for the United States of pursuing value-based policies.

The fifth feature of values-based foreign policy is that it reflects the spirit of American exceptionalism and adherence to the ideology of liberalism, which are among the main elements of American political culture. Liberalism has produced ideas that link how a country is governed with world security and prosperity, like the theory of democratic peace. These ideas advocate that liberalism includes universal values and recommend the adherents of liberalism to take action to spread liberal political and economic systems. They provide strong motivation for American administrations to strive to spread liberal values. It can be observed that the American administrations, influenced by these ideas, gave weight to one of the two positions. The first one is liberal internationalism. Those who adopt this stance attach importance to cooperation between democracies, to the development of international law and institutions, and to the spread of liberal democracy and market economy by peaceful means. The second position advocate more active use of existing capabilities of democracies, including military force, for the spread of democracy and market economy. Although unilateralism and interventionism have always existed in American foreign policy in one form or another, and they were often justified by appealing to the discourse of values, the tendency towards them became more evident after the Cold War. This tendency is largely encouraged by America's being the sole superpower and the neo-conservatism.

The other main element of American political culture, American exceptionalism, led the United States to see itself as a nation with the mission of defending democracy and freedoms, thus encouraging the realization of values through foreign policy.

In conclusion, the above-mentioned five characteristics can be considered as the underlying reasons for the USA's adoption of spreading and protecting values through its foreign policy. Unless radical changes occur in American domestic policy and world politics that will force the United States to act differently, it can be expected that there will not be a great shift in American conceptualization and practice of value-based foreign policy. 


\section{Giriş}

ABD, 1776 yılında yayınlanan Bağımsızlık Bildirisi ve bir süre sonra kabul edilen anayasası dikkate alındığında siyasal, ekonomik ve hukuki sistemlerini, liberal ideolojinin hak ve özgürlükler, hukuk devleti ve piyasa ekonomisi öğretilerine dayanarak inşa eden ilk ulus-devlet olmuştur. Liberal bir ülke olarak, iç siyasi yapısında benimsediği değerlerin kendi dışındaki dünya ile ilişkilerinde ne ölçüde karşılık bulacağı konusu, kuruluşundan itibaren ABD’nin gündeminde kalmıştır.1

ABD, kendisini Avrupa merkezli dünya siyasetinin dışında tuttuğu (izolasyon politikası izlendiği) dönemde, diğer devletlerin takip edeceği örnek demokrasi olmak yoluyla değerleri yaymayı hedeflemiștir. Bu nedenle, ekonomik faaliyetlerin serbestliği ilkesi hariç liberal değerleri (Amerikan değerlerini) dış politikaya yansıtmamayı tercih etmiştir. Başkan Woodrow Wilson, 1917 yllında ABD'yi I. Dünya Savaşına sokarak, dünya siyasetinde aktif rol alma politikası izlenmeye başlamıştır. Wilson, demokrasinin yayılması ve dünya siyasetinin liberal değerlere göre dönüştürülmesini içeren bir vizyonu benimsemiştir. Wilson'dan sonra izolasyon politikasına geri dönen ABD, Aralık 1941 'de II. Dünya Savaşına girmiş ve liberal ilkelere uygun bir dünya düzeni inşa etmeyi tekrar denemiştir. Soğuk Savaş ortamı buna müsaade etmeyince ABD, Batı bloğunun liberal değerler temelinde kurulmasına öncülük etmiştir. Blok dışı dünya ile ilişsilerde ise esas olarak stratejik öncelikler belirleyici olmuştur. Soğuk Savaş sonrası dönemde Amerikan dış politikasında demokrasinin yayılması ve insan haklarının korunması misyonu, komünizmi yenilgiye uğratma misyonunun yerini almış ve dış politikada yeni uzlaşmanın temelini oluşturmuştur².

1 Bu bağlamda değerler ile çıkarlar arasında ne tür bir denge kurulacağı tartışılmıştır (Chollet \& Lindberg, 2007: 3).

2 Değerlerin yayılması konusunda Amerikan siyasetinde uzlaşma olduğunu gösteren çok sayıda delil sunmak mümkündür. Örneğin, Temsilciler Meclisi'nde dış politikanın görüşüldüğü bir oturumda Cumhuriyetçi Parti üyesi Edward Royce, “... demokrasi, Birleşik Devletler dış politikasının temel unsurlarından birisidir" ifadesiyle; Demokrat Parti üyesi Eliot Engel ise "... demokratik değerlerimizin dünya çapında yayılması ... dış politikamızın merkezinde yer almalıdır" ifadesiyle, bu uzlaşmayı açıkça vurgulamıştır (The House of Representatives, 2018: 1, 3). Demokrasi ve özgürlükler söylemine çok mesafeli duran Trump yönetiminde bile değerlerin yayılması ve korunmasına yönelik hedeflerin resmen dış politika hedefleri arasında yer almaya devam etmesi de uzlaşmanın ne kadar sağlam olduğunun bir delili olarak alınabilir (Congressional Research Service, 2000: 1). 
Bu makale, liberal değerlerin yayılması ve savunulmasının Amerikan dış politikasında bir süreklilik unsuru olması olgusunu anlamaya yönelik bir çabadır. Makalede, Amerikan yönetimlerinin değerler ve dış politika konulu söylemleri, stratejileri ve uygulamaları ${ }^{3}$ araştırıldığında beș özelliğin öne çıktığı, bu özelliklerin değerlere dayalı dış politikayı ABD'ye özgü kıldığı ve değerleri elde etme çabasının Amerikan diş politikasında bir süreklilik unsuru olmasını sağladığı varsayılmıștır. Söz konusu özellikler şunlardır: Amerikan yönetimleri, uzun vadede değerler, Amerikan çıkarı ve genel çıkarın uyum içinde olduğunu kanaatine sahip olmuştur; değerler siyaseti izlenirken, güncel Amerikan çıkarları da gözetilmiştir; Amerikan yönetimleri, değerlere dayalı hedeflere ulaşmak için şartlara göre farklı stratejiler izlemiştir; karşılaşılan maliyetler dolayısıyla politika değişiklikleri yapılabilmiștir; değerleri rehber edinen dış politika, Amerikan siyasal kültürü ile uyumludur. Makalenin alt başlıklarında, her bir özellik sırasıyla değerlendirilecektir. Çalışmanın bulguları, sonuç bölümünde sunulacaktır.

\section{Liberal Değerler, Amerikan Çıkarı ve Genel Çıkarın Uyumu Anlayışı}

Amerikan yönetimleri; demokrasi, insan hakları ve piyasa ekonomisinin yayılması ve tehlike ile karşılaştıklarında savunulması ile Amerikan çıkarı ve insanlığın ortak çıkarı (yani genel çıkar) arasında uyum olduğunu iddia eden bir söylem geliştirmiştir. Bu söyleme göre ABD, liberal değerleri yayma ve tehditler karşında onları savunma misyonunu üstlenmelidir. Bu çerçevede, değerlerin diğer toplumlar tarafından benimsenmesini ve uluslararası sistemin de değerlere göre inşa edilmesini (yani liberal uluslararası düzen kurulmasını) sağlamak için çaba göstermelidir. Çünkü liberal değerler üniversal değerlerdir. Onlar, ABD içinde sosyal barış ve refahın temelini oluşturduğu gibi, dünya genelinde barış ve refahın temelini oluşturma kabiliyetine sahiptir (bkz. aşağıda beşinci bölüm). Dolayısıyla onların yayılması ve korunması hem ABD'nin hem de insanlığın çıkarınadır. Değer, Amerikan çıkarı ve genel çıkarı uyum içinde gösteren bu kabul, Amerikan diş politika eylemlerinin yöneldiği başlica hedefler olarak sıklıkla tekrarlanan "uluslararası barıș ve istikrar" hedeflerinin "barış" ayağının fikri dayanağıdır. Aynı zamanda, ABD’nin diğerlerinin hukukunu da gözeten / erdemli dış politika izlediği (yani gücünü evrensel ilkeleri gözeterek kullanan devlet olduğu) iddiası da değer, Amerikan çıkarı ve genel çıkarın uyum içinde olduğu kabulüne dayanmaktadır (Bouchet, 2013: 34).

Değer, Amerikan çlkarı ve genel çıkarın uyumu söylemi, ABD’nin bölgesel ve küresel siyasete katılımı ile eş zamanlı olarak dile getirilmiştir. İzolasyon siyaseti izlenen dönemde, Amerikan ulusal güç unsurlarının zayıflı̆̆ dikkate alınarak bölgesel ve küresel siyasete sınırlı düzeyde katılım gerçekleşmiştir. Amerikan değerlerinin yayılması fikri bu dönemde de mevcuttur. Ancak, 
izolasyon siyasetinin doğası ile uygun olarak, ABD’yi diğerlerinin izleyebileceği bir model ülke yapmak ve seçimi diğer toplumlara bırakmak ile sınırlıdır (Perkins, 1994: 466). Yine de bu dönemde ABD, 1823 tarihinde ilan edilen Monroe doktrini, Latin Amerika ve Doğu Asya'da izlenen "açık kapı" politikası ve 1898-1902 yılları arasında Küba ve Filipinler'de vuku bulan İspanya-ABD savaşı örneklerinde değer, Amerikan çıkarı ve genel çıkarın uyum içinde olduğu mantığı ile hareket edeceğinin ilk işaretlerini vermiştir. Çünkü bu olaylarda ABD’nin davranışları; bireysel özgürlükler, serbest pazar ekonomisinin refahı artışı vasıtasıyla temsili yönetimi teşvik etmesi ve despot yönetimlerden kurtulmanın gerekliliği argümanları da kullanılarak açıklanmıştır (Walker, 2019: 11-12).

Amerikan tarihinde, değer, Amerikan çıkarı ve genel çıkarın uyumu varsayımına dayanan en kapsamlı vizyon, başkan Wilson tarafından ifade edilmiştir. Onun dünya siyasetine ilişkin fikirleri Wilsonculuk diye adlandırılmıştır.4 Wilson, özünde devlet düzeyinde temsili demokrasi ve piyasa ekonomisinin yayılmasını, dünya siyasal sistemini de liberal ilkeler doğrultusunda dönüştürülmesini savunmuştur. Wilson'ın devlet ve sistem düzeyinde değişimi, hem ABD’nin barış içinde ve müreffeh bir ülke olarak yaşaması için dışarıda uygun bir ortamın oluşması ${ }^{5}$ hem de dünya barışının tesisi için bir araç olarak gördüğü değerlendirilebilir. Çünkü Wilson, demokrasinin yayılması ile özgür halklardan oluşan demokratik devletler ortaya çıkacağını, bu devletlerin bir araya gelmesiyle oluşacak uluslararası toplumun da dünya barışının tesisini ve sürdürülmesini sağlayabileceğini öngörmüştür (Ruggie, 1997: 93-95; Smith, 1994: 84-86).

Wilsonculuk, devlet düzeyinde demokrasinin yayılmasını iki bakımdan değerlendirmiştir. Birincisi, dünyanın tekrar büyük bir savaşa sürüklenmesinin önlenmesi ile otoriter yönetimlerin varlığı arasında bağ kurmuştur. Otoriter yönetimleri, ABD’nin güvenliği ve dünya barışı için tehdit olarak görmüştür. Liberalizmden esinlenerek geliştirilen bu tehdit algısına göre otoriter yönetimler, sözünü tutmayan, akitlerine riayet etmeyen, güvenilmez yönetimlerdir. Aynı zamanda onlar, diğer toplumlar üzerinde tahakküm kurmak isterler. I. Dünya Savaşı öncesinde büyük devletlerin onların genişleme iştahını sınırlandırmak için izlediği denge siyaseti başarısız olmuş ve insanlığı felakete götürmüştür. Aynı felaketin tekrar yaşanmasını önlemenin yollarından birisi

4 Wilsonculuk kavramı ile bazen uluslararası ilişkiler yaklaşımları arasında yer alan idealizm ve liberal enternasyonalizm de kastedilmektedir. Wilson, vizyonunu, ABD’nin I. Dünya Savaşında Nisan 1917'ye kadar savaş dışı kalışını ve daha sonra da savaşa girişini, "insanlık yüce idealine hizmet etme" ile açıklayarak geliştirmeye başlamıștır (Dunne, 2000: 31). Bu vizyon, Wilson Prensiplerinin ilanı, Wilson'un çeşitli konuşmaları ve Paris'te 1919'da yapılan barış görüşmeleri sırasında ifade edilen fikir ve öneriler ile olgunlaşmıştır.

5 Michael Dunne (2000: 35), Amerikan çıkarı ile genel çıkarı uyumlu görmenin yeni bir olgu olmadığını, "Monroe doktrininde içkin olan "Amerikan barış ve mutluluğu" için dışarıda olumlu şartların oluşturulması gerektiği fikrini”, Wilson’un “dünyanın tamamında olumlu şartlar oluşturulması olarak anladığını” belirterek vurgulamıştır. 
de otoriter yönetimlere karşı durulması ve demokrasinin teşvik edilmesidir. İkincisi, Wilsoncu bakış açısına göre ideal devlet; yönetilenlerin rızasına dayanan, güçler ayrılı̆̆ı ilkesini hayata geçiren ve serbest piyasa ekonomisini benimseyen devlettir (liberal-kapitalist devlet veya kısaca liberal demokrasi). Barışın sürdürülmesi ve refahın artışı için liberal demokrasi gerekliliktir (Dunne, 2000: 31; Thompson, 2010: 33; Smith, 1994: 88).

Uluslararası sistemin dönüştürülmesi konusunda Wilsonculuk, barışın sürdürülmesi için, uluslararası siyasetin liberal ilkelere göre inşa edilmesini, bir başka ifadeyle normatif (rule-based) uluslararası düzen kurulmasını önermiștir. Söz konusu düzen, kendi rızaları ile bir araya gelen demokrasiler tarafından kurulacaktır. Bu düzende, uluslararası hukukun gelişmesi, anlaşmazlıkların barışçı yöntemlerle çözümü ve devletlerin saldırganlığa karşı birlikte korunması (kolektif güvenlik) sayesinde barışın sürekliliği sağlanabilecektir. Uluslararası düzenin ekonomik boyutuna ilişkin Wilsoncu vizyon, serbest ekonomik ilişkilerin bireyi güçlendireceği, rızaya dayalı yönetim taleplerini artıracağı ve toplumu zenginleştireceği yönündeki klasik argümanları tekrarlamıştır. Özetle, devlet ve sistem düzeyinde fikir ve önerileri dikkate alındığında Wilsonculuk, devletlerin rejimini ve dünya siyasetini Amerikan devletinin benimsediği liberal fikirlere göre dönüştürme çabasıdır ve Amerika için iyi olan dünya için de iyidir anlayışına dayanmaktadır (Smith, 1994: 90; Gourevitch, 2007).

Wilson yönetimi, uygulamada uluslararası siyasetin dönüşümünü öne çıkarmış; demokrasinin yayılması üzerinde nispeten az durmuş; ekonomik boyutta ise serbest piyasa ekonomisinin söylem düzeyinde teşvikinin ötesine geçen bir girişimde bulunmamıștır (Thompson, 2010: 36; Smith, 1994: 87, 93). Uluslararası siyasetin kurumsal mekanizmalar yoluyla dönüşümü, Wilsonculuğun en dikkat çeken önerisidir. Bu kapsamda kolektif güvenlik, anlaşmazlıkların barışçı yollarla çözümü ve uluslararası hukukun geliştirilmesi işlevlerini yüklenmesi için Milletler Cemiyeti'nin ve onun çatısı altında Adalet Divanı'nın kurulması önerilmiştir. Ayrıca küresel örgütlenmenin, bölgesel düzeyde de Pan-Amerikan Özgürlük Paktı gibi çok taraflı örgütler vasıtasıyla desteklenmesi düşünülmüştür (Huber, 2015: 11). Wilson'un demokrasinin yayılmasını hedefleyen en somut öneriler ise self-determinasyon ilkesinin hayata geçirilmesi kapsamında yaplanlardır. Bunlar arasında, Avrupa'da (tam olarak savaşta yenilen Almanya, Avusturya-Macaristan ve Osmanlı Devleti topraklarında) kendisini yönetme kabiliyetine sahip etnik toplulukların bağımsızlığını kazanması, kurulacak olan Çekoslovakya, Polonya ve Yugoslavya gibi ülkelerde ve savaşta yenilen devletlerde temsili demokrasi ve güçler ayrılığını benimsemiş yönetimler kurulması önerileri en dikkat çekenlerdir (Smith, 1994: 87-89).

ABD, izolasyon politikasını kalıcı olarak terk ettiği Aralık 1941 tarihinden Soğuk Savaşın başlamasına kadar geçen sürede, Amerikan çıkarı ile genel çıkar 
arasında bağ kuran Wilsoncu vizyonu yeni şartlarda canlandırmak için çaba sarf etmiştir. Bu kapsamda sömürgeciliğin tasfiyesi, demokratik yönetimler kurulması (1945 yazında Polonya'da hükümetin kurulması konusunda Sovyetler Birliği ile yaşanan kriz, demokratik yönetim yanlısı tutuma bir örnektir), nüfuz alanları oluşturulmasına karşı çıkılması gibi ilkeleri gündeme getirmiştir. Bunların hayata geçirilmesi için MC'nin yerine, Birleşmiş Milletler örgütünün (BM) kuruluşuna öncülük etmiştir. BM sistemi, dünya ekonomisinin ana hatlarıyla liberal bir temelde şekillendirilmesini sağlayacak kurumları ve insan hakları alanında düzenleme yapılmasını da içermesi nedenleriyle Wilsoncu vizyonun uygulama alanını genişletmiştir (ayrıntılı değerlendirme için bkz. Smith 1994: 113-119). Ancak Soğuk Savaş nedeniyle BM sisteminin dünya liberal düzeninin omurgasını oluşturması mümkün olmamıştır.

Soğuk Savaş döneminde Amerikan dış politikasında stratejik öncelikler belirleyici olmuştur. Örneğin, müttefiklerle ilişkilerde istisnai durumlar haricinde demokrasinin zayıflığı veya özgürlüklerin ihlali gündeme gelmemiştir. Özellikle stratejik önem atfedilen coğrafyalarda bulunan müttefik devletlerle ilişkilerde, demokratik değişimi teşvik etmenin istikrarı bozabileceği kaygısı ile hareket edilmiştir6. Ayrıca stratejik önceliklerin karar verme sürecinde ağırlık kazanması, içeride kamuoyu desteği sağlanması amacıyla değerler diline başvurma ihtiyacını azalmıştır. Değerlerin dış politikada azalan rolü, Amerikan çıkarı ile genel çıkar arasında bağ kurulmasını da zayıflatmıştır.

Yine de Soğuk Savaş şartları, ABD’nin dıș dünyayla ilişkilerinde değerleri bütünüyle önemsiz hale getirmemiştir. İlki, Amerikan yönetimleri, Amerikan liderliğini benimseyen devletler grubunu değerler üzerinden tanımlamayı tercih etmiş ve "hür dünya" adını vermiştir. Ayrıca Amerikan ittifaklar ağının en önemli parçası olan NATO'yu başta demokrasi olmak üzere aynı değerleri benimseyen ülkelerden oluşan bir topluluk olarak nitelendirmiştir. Rakip grupta yer alan devletleri ise totalitarizmin temsilcileri olarak görmüştür. Truman doktrininden itibaren demokrasilerle totaliter dünya arasındaki mücadele olarak algıladığı Soğuk Savaşta hür dünyanın insanlık adına mücadele verdiğini düşünmüştür. Böylece formül küçük bir değişiklikle, ABD liderliği altında hareket eden bloğun çıkarı ile insanlığın çıkarı özdeş gösterilerek ifade edilmiştir. İkincisi, Soğuk Savașın sonlarına doğru önce Carter yönetimi insan haklarına dayalı dış politika izlediğini, arkasından da Reagan yönetimi insan hakları boyutunu da içeren demokrasinin yayılması politikası izlediğini belirtmiştir. Bu iki yönetimin izlediği siyasalarda, aşağıda belirtileceği gibi, insan hakları ve demokrasinin araçsallaştırılması (rakip bloğu zora sokma ve özellikle Reagan yönetiminin neo-liberal ekonomi politikalarını ABD ile işbirliği yapan azgelişmiş ülkelere benimsetme hedeflerine sahip olmaları nedeniyle)

6 Bu genellemenin istisnası, müttefiklerde demokrasinin gelişmesinin istikrar bağlamında teşvik edilmesidir. Örneğin, Latin Amerika ülkelerinde otoriter yöneticileri destekleyen ABD, şartlar uygunsa, demokratik reformların siyasal istikrarı artıracağı, dolayısıyla ABD'nin güvenliği için yararlı olacağı varsayımı ile hareket etmiștir (Smith 1994; 81-82). 
daha belirgindir. Yine de bahsedilen siyasalar, demokratik yönetimin kuvvetlendirilmesine yönelik hedefler de içermişlerdir (Forsythe, 1995:117-119, 122-124). Bu anlamda Carter yönetiminin insan hakları, Reagan yönetiminin ise demokrasinin yayılması ve ekonomik liberalleşme politikaları, Wilsoncu vizyonu tekrar canlandırıcı bir boyuta da sahiptir.

Sovyet bloğunun 1989-1991 yıllarında dağılması, Batıda demokrasilerin siyasi, askeri, ekonomik ve kültürel alanlarda totaliterliğe üstün gelmesi olarak anlaşılmıştır. Buna paralel olarak Batıda liberal sosyo-ekonomik ve siyasal sistemlerin insanlığın geliştirdiği en üstün sistemler olduğu fikri gelişmiştir. Böyle bir ortamda ABD içinde farklı siyasal eğilimler, hem ABD'nin hem de insanlığın güvenliği ve refahı için (genel çıkar adına) dünya çapında demokrasinin yayılması, insan haklarının korunması ve ekonomik liberalleşmenin desteklenmesi konusunda uzlaşmışlardır. Bunun bir sonucu olarak H. W. Bush yönetiminden itibaren bütün yönetimler (Trump yönetimi hariç) demokrasinin yayılması ve insan haklarının korunmasına yönelik söylemler geliştirmiştir. Söylemlerin dış politikada ağırlığı ve hayata geçirilme yöntemleri, bir yönetimden diğerine farklılık göstermiştir. Fakat özellikle Clinton, $\mathrm{W}$. Bush ve Obama yönetimlerinin ortak paydası, ABD'nin güvenliği ve refahı ile demokrasinin yayılması arasında kuvvetli bağlar kurmaları ve bu çerçevede Amerikan çıkarı ile genel çıkarı uyumlu görmeleri olmuştur (Thompson, 2010: 43-45; Brancati, 2014: 712-713).7

\section{Değerler Siyaseti ve Kısa Vadeli Amerikan Çıkarları}

Değerlerin yayılması ve savunulmasının uzun dönem Amerikan çıkarı olarak kabul edilmesi, ABD'nin dünya genelinde demokrasi ve özgürlüklerin kuvvet bulmasına öncelik vereceğini, kendi çıkarlarını ise bu çerçeve içinde arayacağını ima etmektedir. Ancak ABD bir ulus-devlettir ve ulus-devletlerin oluşturduğu anarşik niteliği ağır basan bir dünya sistemi içinde yer almaktadır. Ulus-devlet modelinde dış politika hedeflerinin kalıcı olabilmesi için, uzun dönemde ülkenin yararına olacağına inanılması yeterli değildir. Hedefleri elde etmek için izlenen politikaların güncel ekonomik, stratejik ve diğer çıkarlara hizmet ettiğinin gösterilmesi de gerekir. Aksi takdirde hedeflere ulaşmak için insan ve kaynak tahsisi sağlanamayabilir. Amerikan yönetimleri, değerleri gerçekleştirmeye yönelik izledikleri siyasalar ile çoğu zaman ABD'nin ekonomik, siyasi ve güvenlik çıkarlarını (kısa vadeli/güncel çıkarlarını) gerçekleştirmeye çalışmıştır. Bu konuda sağlanan başarı ölçüsünde, değer ile güncel çıkarın uyumlu görünmesi ve dolaysıyla dış politikada değerleri elde etmeye yönelik hedeflerin kalıcılığı sağlanabilmiştir.

7 Bush'un dünya siyasetini dönüştürme anlayışı, Wilsoncu çizgiyi sınırlarına kadar zorlayan bir anlayıștır. Hatta Wilsoncu dış politikanın çok taraflılık ve uluslararası normlara uygun davranmayı gerektirdiğini savunanlara göre W. Bush'un tek yanlı ve askeri güç kullanımı merkezli değerler siyasetinin Wilsonculukla bir alakası yoktur (örneğin bkz. Ikenberry, 2011, 262-263, 267). 
Değerlere dayanan siyasalar izlenirken aynı zamanda belirli Amerikan çıkarlarının elde edilmesi, Amerikan dış siyasetinde yeni bir olgu değildir. 19. yüzyılda izlenen açık kapı politikası, serbest ekonomik ilişkilerin, ticarete taraf olan ülkelerde refahı artıracağı ve içeride demokrasiyi, dışarıda ise devletler arasında barışçı ilişkileri teşvik edeceği gerekçesiyle savunulmuştur (Ikenberry 2011: 172). Ancak açık kapı politikasından herkesten çok ABD ekonomik yararlar temin etmiştir. Ayrıca Latin Amerika örneğinde açık kapı politikası, bölgede Amerikan nüfuzunu artırmış; Çin örneğinde ise Avrupalı devletlerin bu ülkeyi kendi aralarında etki alanlarına bölmelerini önlemekte yararlı bir araç olmuştur.

Wilson yönetiminin idealist politikalar vasıtasıyla ABD’nin güncel siyasi çıkarlarını gerçekleştirmesine ilişkin üç örnek verilebilir. Birincisi, Wilson yönetimi ABD’nin dünya siyasetinde belirleyici rol alması için vaktin geldiğini düşünmüştür. Wilson'un, ABD’nin bu rolü diğerleri ile işbirliği (yani çoktaraflılık) temelinde icra etmesini öngördüğü için, Amerikan hegemonyası iddiasında bulunmadığı söylenebilmektedir. Fakat Wilson'un uluslararası sistemin demokratik dönüşümüne yönelik önerileri, Amerikan hegemonyasının zeminini oluşturan öneriler olarak da değerlendirilebilir (Gourevitch, 2007: 27; Bouchet, 2013: 43). Çünkü bu önerilerin, zamanın en büyük ekonomik gücü haline gelen ABD'yi, kurulması tasarlanan sistemde merkezi bir konuma yerleștirmesi mukadderdi. İkincisi, zamanın en acil uluslararası güvenlik sorunu, Avrupa'da yaşanan siyasi istikrarsızlıktı. Avrupa'da istikrarın belkemiğini Almanya-Fransa barışının oluşturabileceğini değerlendiren Wilson yönetimi, bu barışın, her iki ülkenin de demokrasi ile yönetilmesi halinde gerçekleşebileceğini öngörmüştür. Böylece demokrasinin yayılması, güvenliği elde etme aracına dönüşmüştür (Smith, 1994: 97-99). Üçüncüsü, Wilson yönetiminin geliştirdiği demokrasi söylemi, Batı medeniyetine ideolojik alanda meydan okuyan ve Rusya'da iktidarı ele geçiren Bolşeviklere karşı alternatif bir ideolojik duruş sağlamıștır. Demokrasi söylemi vasıtasıyla Bolşeviklerin, savaş nedeniyle istikrarsızlaşan Avrupa ülkelerinde siyasal çalkantılara yol açma imkanının kısıtlanması (Gourevitch, 2007: 27); self-determinasyon söylemi ile de Bolşevizm kaynaklı fikirlerin sömürgelerde etkisinin kırılması hedeflenmiştir (Smith, 1994: 90).

Soğuk Savaş döneminde Amerikan dış politikasında demokrasi ve özgürlükler söylemi ve pratiğinin Sovyet bloğundan algllanan tehditler ile mücadele bağlamında ele alındığı söylenebilir. Soğuk Savaşta ABD, Batı Avrupa ve Japonya dışındaki coğrafyalarda yer alan müttefikleri ile ilişkilerinde demokrasinin zayıflığı veya özgürlüklerin ihlali gibi konuları tali meseleler olarak görmüştür. Almanya ve Japonya örneklerinde bile bu iki ülkenin liberal sosyo-ekonomik siyasal yapıları kabul etmesini sağlayarak, Sovyetler bloğu ile ilişki geliştirebilecek (radikal) unsurların canlanmasını önlemek istemiştir. Diğer coğrafyalarda demokrasiyi yayma ve özgürlükleri teşvik etme çabaları, özü itibariyle rakip blok ile sürdürülen mücadeleden soyutlanarak anlaşılabilecek 
çabalar değildir. Örneğin Carter yönetiminin insan haklarını söylemi, ABD'nin liderlik rolünün iç siyasette sorgulanmasını önlemeye yönelik bir çaba olarak da değerlendirilebilir. 1970'lerin ilk yıllarında salt güç dengesi mantığı ile izlenen yumuşama politikası, Amerikan siyasal kültüründe yer alan değerlerin hiçe sayılması olarak algılanmış; Amerikan prestijine büyük darbe vuran Vietnam Savaşı ise özellikle askeri alanda ABD'nin uluslararası yükümlülükler üstlenmekten çekinmesine (Vietnam sendromu) neden olmuştur. Carter'ın insan hakları söylemi, dış politikaya yeni bir misyon vermek suretiyle ABD'nin köşesine çekilmeyi tercih etmesini engelleyici bir işlev görmüştür (Pee \& Schmidli, 2019a: 20; Gourevitch, 2007: 30). Reagan yönetimi ise demokrasiyi yayma politikasının, şeytan imparatorluğu diye adlandırdığı Sovyetler Birliği'nde ve müttefiklerinde değişim isteyen unsurları desteklemek bakımından meşru bir zemin sağlama işlevine önem vermiştir (Søndergaard, 2019: 36).

Reagan yönetiminin neo-liberal ekonomi politikaları müttefik ülkelere kabul ettirme çabası da idealist siyasaların realist boyutuna diğer bir örnektir. Reagan, Batı dünyasında refah devleti anlayışının ciddi sıkıntılarla karşılaştığı 1970'li yılların hemen ertesinde, Ocak 1981'de, iktidarı devralmıștır. 1970'lerin son yılları, Batıda ekonomik sorunların toplumun ve siyasetin gündeminde öne çıktığı ve neo-liberal politikaların bir alternatif olarak sunulduğu yıllardır. Reagan yönetimi Üçüncü Dünya'daki müttefiklerine, serbest ekonomik ilişkilerin demokrasiye yönelişi kuvvetlendireceği anlayışıyla, neo-liberal ekonomik politikaları benimsemelerini salık vermiştir (Søndergaard, 2019: 47). Ancak neo-liberal politikaların ABD (ve dünya ekonomisini yönlendiren kurumlar) tarafından hararetle teşvik edilmesi, hedef ülkelerin, ABD'nin yeniden dizaynına büyük katkıda bulunduğu dünya ekonomik sistemi ile bütünleşmelerini sağlamaya yöneliktir. Dolayısıyla ABD'nin güncel ekonomik ve siyasi çıarlarına da hizmet etmiştir. Hatta bu son boyut, demokrasinin yayılması boyutundan çok daha fazla öne çıkmıştır.

Serbest ekonomik ilişkilerin bir değer olarak savunulmasını, Soğuk Savaş sonrası yönetimler de sürdürmüştür. Onlar arasında neo-liberal ekonomik politikaların yayılması ve dünya ekonomisinin kurumlarının geliştirilmesine en fazla önem veren Clinton yönetimidir. Dünya ekonomisinde liberal dönüşümün (artık daha popüler ismiyle küreselleşmenin) ivme kazandığı 1990'lı yıllarda iktidarda bulunan bu yönetim, bir taraftan kendisinden önceki yönetimler gibi diğer toplumlarda piyasa ekonomisi güçlendiğinde arkasından demokratikleşmenin geleceği beklentisine sahip olmuş, diğer taraftan küreselleşmenin ABD’nin desteklediği bir çizgide ilerlemesini sağlamak gibi güncel bir çıkarı gerçekleştirmeye çalışmıştır.

Soğuk Savaş sonrası dönemde, değerleri elde etmeye yönelik siyasalar ile güncel çıarların elde edilmesi olgusu, siyasal/askeri alanlarda daha belirgindir. Çünkü bu dönemde demokrasi ve insan haklarının etkileme aracı 
olma ve sistem dışı olarak nitelenen güçlerle mücadelede yararlı dayanaklar olma özellikleri önem kazanmıştır. Birincisi ile başlarsak, devletleri ve diğer aktörleri etkileme imkanı, demokrasi söylemine içkin olan temel hak ve özgürlüklerin evrensel kabul görmesi (BM insan hakları sözleşmelerinde yer almaları nedeniyle) ve onları savunmanın insanlığın yarına olduğu (ahlaki gerekçe) kabulünden kaynaklanmaktadır. Hak ve özgürlüklerin bu iki niteliği, gerçek niyetleri ne olursa olsun, onları savunanlara, muhataplarına karşı demokratik reform, insan haklarının iyileștirilmesi ve ekonomik reform gibi taleplerini meşru talepler olarak dile getirme imkanı vermektedir. ABD, bu imkanı, demokrasinin yayılması amacı ile geliştirdiği enstrümanlar ile daha etkin kullanmaya çalışmıştır. Bu enstrümanlar hem ABD’ye insanlığın iyiliği için çalışan ülke olma imajını inşa etme ve hem de diğer toplumları doğrudan etkileme araçlarıdır. Amerikan Dışişleri Bakanlığı'nın ülke bazında hazırladığı insan hakları raporları, bunlardan ilkidir. İlk insan hakları raporu, Carter yönetimi tarafından hazırlanmıștır. Reagan yönetimi, dış politika alanında selefine yönelttiği bütün eleştirilere rağmen, insan hakları raporu yayınlanmaya devam etmiştir. Takip eden yönetimler de aynı yolu izleyince raporun yayınlanması gelenek haline gelmiş; öyle ki, demokrasinin yayılmasından istisnai olarak bahseden Trump yönetimi bile bu geleneği sürdürmüştür. Diğer bir araç, demokrasinin yayılması amacıyla fikirler üretilmesidir. Bu işlevi daha çok yarı resmi veya sivil düşünce kurumları yerine getirmiştir. Üçüncü araç, ABD'nin demokrasi taraftarı diye nitelendirdiği ve irtibat kurduğu muhalif gruplara fikri, mali ve teknik konularda destek sağlamak hedefiyle çeşitli resmi ve yarı resmi kuruluşların yürüttüğü demokrasiyi destekleme programlarıdır. "Amerikan karar vericilerin radikal diye nitelendirdiği, dolayısıyla Amerikan çlkarlarını tehdit ettiğini düşündüğü" muhalifler, bu programların kapsamı dışında bırakılmıştır (Pee \& Schmidli, 2019: 296-299; Huber, 2015; 13-14; Chollet \& Lindberg, 2007: 17).

Sistem dışı olarak nitelenen güçlerle mücadelede bağlamında Amerikan yönetimlerinin demokrasinin savunulması ve ağır insan hakları ihlallerini, çoğu zaman haydut devlet veya başarısız devlet diye nitelendirilen devletlere karşı veya uluslararası terörizm (ona destek veren devlet de dahil) ile mücadele kapsamında gündeme getirdikleri söylenebilir. Dolayısıyla bu bağlamda değerleri esas alan siyasalar, demokrasiyi yaymanın ve insan haklarını korumanın yanı sıra, güncel güvenlik çıkarlarını elde etmenin aracı olmuştur (Singh, 2014: 99-100). Bu olguyu, ABD’nin başlıca müdahalelerinde tespit etmek mümkündür. Örneğin, 1999'da NATO şemsiyesi altında icra edilen Kosova müdahalesi, hem Kosova halkını Sırbistan'ın ağır hak ihlallerine karşı koruma hem de Balkanlar bölgesinde Amerikan (Batı) çıkarlarını gerçekleştirme boyutlarına sahiptir. Diğer bir örnek W. Bush yönetiminin terörle mücadele

8 The National Endowment for Democracy (NED); USAID'e bağlı The Office of Transition Initiatives; Dıș İşleri Bakanlığı çatısı altında faaliyet yürüten The U.S.-Middle East Partnership Initiative (MEPI) ve Human Rights and Democracy Fund gibi kuruluşlar. 
politikası ve 2003 yılında Irak'ı işgal etmesidir. W. Bush yönetimi, El Kaide tandanslı radikalizme ve daha genel olarak Irak'taki Saddam Hüseyin yönetimi gibi temel hakları ihlal eden otoriter rejimlere karşı demokrasinin çare olacağını değerlendirmiştir. Bir diğer ifadeyle Wilson yönetimi gibi Bush yönetimi de demokrasi ile güvenlik arasında sıkı bağ kurmuştur. Ancak bu yönetim, demokrasinin yayılması yanı sıra ABD’nin tek süpergüç olma konumunun (Amerikan hegemonyasının) kuvvetlendirilmesi için de çok arzulu olmuştur. İzlediği değerler politikasıyla demokrasiyi yaymanın yanı sıra ABD'ye karşı kafa tutan devlet konumundaki Irak'ı diğerlerine örnek olacak biçimde cezalandırmak ve nihai analizde tek kutupluluğu sürdürmek istemiştir (Butt, 2019; Henriksen, 20017: 196-197, 208; Ikenberry 2011: 261-264).

\section{Yöntem ve Araçlarında Çeşitlilik}

İzalosyon siyasetinin terk edilmesinden sonra Amerikan yönetimlerinin tamamına yakını dış politikalarında değerleri elde etmeye yönelik hedeflere yer vermelerine rağmen, yöntemler ve araçlar (ekonomik, siyasi, askeri, kültürel vb.) üzerinde uzlaşma olmamıştır. Yöntemler meselesine değinen Stanley Hoffmann (1995: 161-162), Amerikan yönetimlerinin müdahaleden kaçınmaktan moral değerler için savaşmaya kadar farklı yollar izleyebildiği tespitinden yola çıkarak, "liberalizmin uluslararası ilişkilere dair fikirleri bir vizyon sunmuştur fakat bir program sunmamıştır" kanaatine ulaşmıştır.

Farklılıkları açıklamak için, yöntemlere ilişkin ortaya çıan iki zıt tutumdan bahsetmek yararlı olabilir. Birinci tutuma göre ABD, değerlere dayanan bir dünya düzeni (pratikte ABD'nin hegemon güç olduğu bir düzen) kurulması için çaba göstermelidir (Henriksen, 2017: 9-10). Bu tutum, kendi içinde ikiye ayrılabilir. Liberal hegemonya öngören tutum, uluslararası işbirliğine öncelik verilmesini; zorlayıcı diplomasi ve askeri müdahale araçları kullanılırken uluslararası hukuka uygunluğa riayet edilmesini savunur. Uluslararası siyasetin liberal değerlere göre işlemesini yeterli görüp, demokrasinin her yerde yayılmasını ikinci plana itenler (Thompson, 2010: 29) veya çok taraflılığa ilkesel bağllık gösteren ve aynı zamanda Amerikan gücünün sınırlılıklarının farkında olanlar (Ikenberry, 2011: 186, 192) bu tutumu desteklemiștir. Diğer alt-tutum, liberal emperyalist tutumdur. Bu tutum temel değerleri reddedenleri dönüştürmeyi veya yenilgiye uğratmayı önenir. Bu amaçla zorlayıcı diplomasi ve askeri müdahale araçlarını öne çıkarır. Değerlerin üniversal niteliğine vurgu yapanlar (ideolojik davrananlar) (Thompson, 2010: 30) ve/veya ABD'nin tek başına yeterince güçlü olduğuna inananlar (Ikenberry, 2011: 255) bu tutumu savunmuştur. Ancak aşağıda değinileceği gibi bu iki alt-tutum arasındaki sınırlar özellikle Soğuk Savaş sonrası dönemde neo-muhafazakarlık ve radikal liberal düşüncelerin de etkisiyle bulanıklaşmıştır. İkinci tutum ise ABD'nin kendi ülkesinde demokrasiyi ilerletmesini önerir. Bu tutumu savunanlara göre, kendini geliştiren ABD; demokrasi, hak ve özgürlükler alanlarında diğerlerine örnek olacaktır. Dolayısıyla değerler adına, kamu diplomasisinden 
askeri müdahaleye kadar herhangi bir faaliyete gerek kalmayacaktır (Henriksen, 2017: 9-10, 22-23, 31-32)

Bir yönetimin hangi tutuma ağırlık vereceği (dolayısıyla hangi yöntemi benimseyeceği ve hangi araçları tercih edeceği) ile karar verme sürecini etkileyen her türlü faktör arasında bir bağlantı kurmak mümkündür. Yine de uluslararası sistemin yapısı ve ABD’nin nispi gücü, ABD’nin kendisine biçtiği uluslararası rol, ABD’nin tehdit algıları, başkanların ve ekibinin liberal fikirlere ve Amerikan istisnacılığı anlayışına bağlılık derecesi, her bir yönetimin selefinden farklı dış politika yürütme arzusu, seçmene verilen sözler ve Amerikan kamuoyunun hassasiyetleri (özellikle maliyetler konusunda) gibi faktörlerin daha belirgin etkiye sahip oldukları söylenebilir (Henriksen, 2017: 22-23; Brancati, 2014: 706-707; Thompson, 2010: 47).

Sayılan faktörlerin çoğunluğu, Amerikan karar vericileri, Amerikan çıkarını genel çıkar içinde aramaktan daha çok güncel Amerikan çıkarlarını dikkate almaya yönelten faktörlerdir. Bunun bir yansıması olarak Amerikan yönetimleri, bir taraftan genel çıkar ile Amerikan çıkarının uyum içinde olduğunu belirten söylemi korurken diğer yandan güncel çıkarları da hesaba katmaları, yöntem ve araçlarda farklılıklara yol açmıştır. Bu farklılıklar hem bir yönetimden diğerine hem de aynı yönetimin farklı gelişmelere karşı tutumunda ortaya çlkmıştır.

Wilson yönetimi, sadece ABD’de demokrasinin olgunlaşmasına odaklanmayı (reel sosyalizm literatürüne atıfla "tek ülkede demokrasiyi") yeterli bulmamış, ABD’nin güvenliği ve refahı için dünya siyasetini dönüştürmek ve kısmen de diğer toplumları demokratikleştirmek istemiştir. ABD’nin dünya siyasetini belirleyen tek güç konumunda olmadığı bilinciyle, dönüşüm vizyonunu çoktaraflılık temelinde (diğerleri ile işbirliği içinde) gerçekleştirmeye çalışmıştır. Araç olarak hukuka, kurumlara ve diplomasiye öncelik verdiğini beyan etmiştir (İkenburry, 2011: 17, 19, 22). Ancak, Wilson'un düşünceleri, demokrasinin yayılmasına önem verdiği ölçüde, değerleri kabul etmeyenlere karşı güç kullanımına kapıyı açık bırakan bir boyuta da sahiptir. Wilson yönetiminin Meksika'ya müdahalesi (1914), Wilsonculuğun zorlayıcı yöntemleri ne ölçüde reddettiğini tartışmaya açmıştır (Thompson, 2010: 30; Smith, 1994: 74, 84).

ABD’nin değerleri elde etmek için izlediği yöntem ve kullandığı araçlarda güncel çıkarları dikkate almaya yönelten faktörlerin etkisini (ve bunun sonucunda ortaya çıkan çeşitliliği) Wilsoncu vizyonu bir şekilde takip eden diğer yönetimlerin uygulamalarında da görmek mümkündür. Soğuk Savaş döneminde bu etki daha belirgindir. Çünkü bu dönemde Amerikan dış politikasını temelde jeopolitik kaygılar yönlendirmiş ve değerler daha çok biz ve onları tanımlamak bağlamında belirleyici olmuştur. Soğuk Savaşın sonuna doğru insan hakları ve demokrasinin dış politika stratejisine dahil edilmesi ise büyük ölçüde rakip blokla mücadele odaklı geliştiği için, niteliksel bir değişim gerçekleşmemiştir. 
Soğuk Savaş sonrası dönemde değerlere ilişkin hedefleri elde etmeye verilen önemin artması, yöntemler ve araçlar konusunda bir uzlaşma üretmemiştir. Geçiş yıllarında iktidarda olan baba Bush yönetimi, dış politika stratejisinde söylem düzeyinde değerlere vurguyu artırmıştır. Örneğin, Dışişleri Bakanı James Baker, "çevrelemeden sonra demokrasi gelir" demiştir (Pee \& Schmidli, 2019b: 294). Fakat artık tek süper güç pozisyonundaki ABD’nin imkanlarını değerler adına seferber etmekten sakınmıştır. Ardılı Clinton yönetimi de demokrasi ile yönetilen devletlerin sayısını artırma ve aralarındaki bağları kuvvetlendirme (enlargement and engagement) siyaseti izlediğini belirtmiştir. Fakat bunu pragmatik bir mantıkla yapmak istemiştir. Bu çerçevede değerlerle ilgili hedefleri, ekonomik imkanları kullanılarak (çoğu zaman neo-liberal politikaların diğer toplumların kabul etmesini teşvik ederek veya zorlayarak) elde etmeye çalışmıştır. Değerleri daha çok sistem dışı güçlerle mücadelede öne çıkarmış; Haiti ve Kosova müdahalelerinde olduğu gibi gerekli gördügünde, insani amaçlara dayanarak ve kısmen tek taraflı (uluslararası toplumun desteğini almaya tam özen göstermeksizin) hareket etmiştir (Hoffmann, 1995: 159, 172; Pee \& Schmidli, 2019b: 295-296).

İktidarı döneminde 11 Eylül 2001 saldırıları yaşanan W. Bush yönetimi, dış politika stratejisinde demokrasinin yayılmasına en fazla yer veren yönetim olmuştur. Bunun temel nedenlerinden birisi, W. Bush yönetiminin, en büyük güvenlik tehdidi olarak gördügü terörizm ve onu besleyen radikalizme karşı çarenin demokrasi olduğunu öngörmesidir. Bu nedenle demokrasinin coşkulu bir şekilde ve her türlü araç (özellikle askeri güç) kullanılarak yayılmasını savunmuştur. Demokrasinin yayılması için Büyük Orta Doğu İnisiyatifi dahil çeşitli projeler geliştirmiş ve yüklü miktarda kaynak tahsis etmiştir. Diğer nedeni, neo-muhafazakar siyasi akımın etkisiyle oluşan, insanlık yararına çalışan ABD’nin demokrasi adına yapacağı işler için başkalarından onay beklemesine gerek olmadığı düşüncesidir. Bu düşünce, zor ile demokrasinin yayılmasının mümkün olduğu düşüncesiyle birleşerek, ABD’yi tek taraflılığa yöneltmiştir. Nitekim W. Bush yönetimi, askeri müdahaleleri müttefikleri ile geniş bir uzlaşma zemini aramadan, sadece kendini destekleyenler ("gönüllüler koalisyonu") ile birlikte yürütmüştür. Yine bu düşünceye dayanarak W. Bush yönetimi, diğer devletleri ABD’nin terörle savaşına destek vermeye zorlamıştır ve destek vermeyenleri dişlamıștır (Ikenburry, 2011: 267; Singh, 2014:108-109).

Halefi Obama yönetimi, tek taraflı ve sadece siyah ve beyazın mümkün olduğu mantığı ile hareket eden Bush yönetiminin stratejisini sürdürülemez ve yanlış bulmuştur. ABD’nin tekrar kendi içinde demokrasiyi güçlendirmeye yönelmesi gerektiğini düşünmüştür. Ancak demokrasinin yayılmasına önem vermeyi de sürdürmüştür. Yöntem olarak çok taraflılığı esas aldığını iddia etmiştir. Ayrıca yumuşak güç unsurlarını kullanmaya önem vereceğini belirtmiştir. Ancak uygulamada Obama yönetimi de selefi gibi El Kaide ve onun çizgisindeki grupları Amerikan değerlerine karşı askeri tehdit olarak görmeye 
devam etmiş; onlarla mücadelede askeri güç unsurlarına ağırlık vermiştir. Bu bağlamda insansız hava araçlarının yaygın kullanımı ve onlarla yapılan saldırılarda çok sayıda masum sivilin ölümü dikkat çekmiştir. Böylece Obama yönetimi, demokrasinin yayılması ile dış politikasının diğer öncelikleri arasında uyumu sağlayan tutarlı bir strateji üretememiștir (Lasher \& Linehart, 2016; 875-879; Pee \& Schmidli, 2019b: 299; Henriksen, 2017; 10).

Özetle değerlere dayanan hedefleri elde etmek için başvurulan yöntem ve araçlar, ilkelerden daha çok konjonktüre göre belirlenmiştir. Amerikan diş politikasına esneklik kazandıran ve bu nedenle moral siyaset izlemenin risklerini azaltan bu olgu, idealist hedeflerin dış politikada kalıcılığına katkıda bulunmuştur.

\section{Değerlere Dayanan Siyaset İzlenmesinde Maliyetlerin Etkisi}

Değerlere dayanan siyaset izlenmesi, ABD için birtakım maliyetlere de sebep olmaktadır. Maliyetlerden bir kısmı (Amerikan kamuoyu desteğinin kaybedilmesi, ekonomik maliyetler, insani maliyetler gibi) ulusal düzeyde ortaya çıkmaktadır. Bir kısmı ise uluslararası hukuka aykırılık, müttefiklerle ilişkilerin zedelenmesi, muhatap devlette istenmeyen gelişmeler (çatışma riskinin artması, istenmeyen liderlerin seçimleri kazanması, yatırımların boşa gitmesi vb. Brancati, 2014: 712) gibi dış kaynaklı maliyetlerdir. Amerikan yönetimleri, bu tür maliyetlerle karşılaşınca (çıkarları zarar görünce) istisnai tercihlerde bulunabilmişler veya tavır değiştirmişlerdir. Böylece değerler siyaseti yürütmenin $\mathrm{ABD}$ için getirdiği riskler azalmıştır. Amerikan dış politikasının değerlere dayanan hedefleri içermeye devam etmesinde bu olgunun da payı vardir.

İstisnai tercihler, hak ve özgürlükler söylemine rağmen bu söylemin gereğini yapmamak veya yapmayı ertelemek şeklinde ortaya çıkmıştır. Bunun en bariz örneklerinden birisi, Clinton yönetiminin 1994 yılında Ruanda'da yaşanan katliamı durdurmak için, ABD’nin çıkarı bulunmadığı gerekçesiyle müdahaleden kaçınmasıdır. Yine Clinton yönetimi, uzunca bir süre Bosna iç savaşına uluslararası çözüm çabalarına, Amerikan çıkarlarının yokluğu gerekçesi ile ciddi katkıda bulunmak istememiştir. H. W. Bush yönetimi ise, 1991 yılının ilkbaharında, Irak yönetimine karşı ayaklanmaya teşvik ettiği Iraklı Kürtler merkezi hükümet karşısında başarısız olunca, sivil nüfusun kitleler halinde göç etmesi ile ortaya çıkan insanlık dramına, uluslararası baskılar artıncaya kadar kayıtsız kalmıștır (Forsythe, 1995: 128-129). Ayrıca daha genel olarak Amerikan yönetimleri, demokrasiyi teşvik ettikleri coğrafyalarda, ABD’nin siyaseten istemediği kişiler veya gruplar (örneğin Hamas) seçim kazandığında, sonuçlara tepki göstermişlerdir (Huber, 2015: 13).

Tavır değiştirme, olay bazında olabileceği gibi kapsamlı politika değişikliği şeklinde de ortaya çıkabilmiştir. Olay bazında tavır değişikliğinin en iyi örneklerden birisi, H. W. Bush yönetiminin 1992 yılının güz aylarında başlattığı, 
Somali'ye insani yardım ulaştırmak için yapılan askeri operasyondur. Bu operasyonu, Amerikan askerlerine karşı yapılan saldırılarda kayıp verilmesi nedeniyle 1993 yılında Clinton yönetimi durdurmuştur. Kimi zaman ise artan maliyetler nedeniyle kapsamlı politika değişikliğine gidilebilmiştir. Örneğin, W. Bush yönetimi, 11 Eylül saldırılarından sonra terörizmle mücadele politikasını, Orta Doğu'da demokrasiyi yayma perspektifi içine yerleştirmiştir. Terörizmle mücadele ve demokrasiyi yayma hedefleriyle Afganistan ve Irak'a askeri müdahalede bulunmuştur. Fakat zor kullanarak demokrasiyi yayma anlayışı, Amerikan iç siyasetinde ve uluslararası ortamda (müttefik ülkeler dahil) yoğun eleștirilere maruz kalmıştır. Eleștiriler arasında müdahalelerin maddi ve insani maliyeti (hem ABD'nin askeri kayıpları hem de işgal edilen ülkelerde sivil ve askeri kayıplar), Irak örneğinde ABD’nin tek taraflı davranması (BM Güvenlik Konseyi kararının yokluğu) ve neo-muhafazakarların dünyayı felakete sürüklediği gibi eleştiriler yer almıştır. Eleştirileri paylaşan halefi Obama yönetimi; içeride demokrasinin gelişmesine önem vermeyi, çok taraflılığı, hukuka uygunluğu ve yumuşak güç unsurlarını kullanmayı esas aldığını iddia ettiği yeni bir değerlere dayalı dış politika izlemeye başlamıştır. $\mathrm{Bu}$ tercihte zorla demokratikleștirme anlayışının getirdiği insani maliyetler, ekonomik maliyetler, iç desteğin zayıflaması ve dünya siyasetinde ABD’nin itibarının yara alması belirleyici olmuștur (Obama, 2007; Pee \& Schmidli, 2019b: 300).

\section{Değerlere Dayanan Dış Politikanın Amerikan Siyasal Kültürü ile Uyumluluğu}

Liberalizm, Amerikan siyasal kültürünü şekillendiren başlıca ideolojidir. Amerikan istisnacılığı da bu kültürün diğer bir temel unsurudur. Değerlere dayanan dış politikanın sürekliliğinde, liberalizm ve istisnacılığın büyük rolü vardır. Çünkü iç siyasal aktörlerin (siyasi partiler, sivil toplum, düşünce kuruluşları vb. gibi) değerler siyasetini benimsemesini ve iç kamuoyunun da değerlerin yayılmasına destek vermesini sağlamaktadır. Ayrıca karar vericilerin içinde hareket ettikleri siyasal çerçeveyi oluşturmaktadır.

Bir ideoloji olarak liberalizm; savunduğu siyasal haklar ve özgürlükler üzerine kurulu siyasal, hukuki ve ekonomik sistemin insanın kendini gerçekleştirmesine ve onurlu bir hayat sürmesine imkan vereceği, toplumun refahının liberal demokrasi ve serbest piyasa ikliminde en üst düzeye çıkacağı, liberal değerlerin evrensel olduğu ve ahlaki tavrın onları savunmayı gerektirdiği ön kabullerine sahiptir. Özellikle bu kabullere dayanılarak geliştirilen dünya barışı ve güvenliği ile ilgili fikirler, dünyada barışın liberal değerlerin yayılması vasıtasıyla gerçekleşeceğini belirtmektedir (Walker, 2019: 6, 8; Hoffmann, 1995: 161).

Immanuel Kant'ın "liberal barış" görüşünün güncel versiyonu olan demokratik barış teorisi, dünya barış ve güvenliği ile ilgili en kapsamlı liberal görüștür. Dünya barıșı ile demokratik yönetim arasında bağ kuran bu teoriye 
göre liberal demokrasilerde seçmenler ve sivil toplum, karar vericileri, anlaşmazlıkları barışçı yollarla çözmeye yöneltecek; liberal bir ortamda farklı devletlerde yaşayan bireyler arasında gelişecek insani bağlar ve serbest ticaret temelinde ortaya çıkan karşılıklı ekonomik bağımlılık da barışçı ilişkilerin kökleşmesini sağlayacaktır. Barış ortamında aynı toplumun üyeleri olma bilinciyle hareket eden devletler ve devlet-dışı aktörler, ortak yararı elde etme prensibi esasında uluslararası normları (ve hatta rejimleri) geliştireceklerdir. Böylece dünyada barışın sürekliliği sağlanabilecektir.

Liberal barış teorisinin dolaylı olarak, onu benimseyenleri değerlerin yayılması için aktif bir tutum takınmaya yönlendirdiği değerlendirilebilir. Çünkü liberal değerleri üniversal değerler olduğu, ahlaki davranışın dayanağını teşkil ettiği ve barışın liberal değerler temelinde korunabileceğini belirtmektedir. Evrensellik, ahlakilik ve barış söylemleri; karar vericileri güçlü bir şekilde motive etme kapasitesine sahiptir.

Diğer taraftan, liberal fikirler temelinde dünya düzeni kurulmasını savunan ve ağırlıklı olarak Soğuk Savaş sonrasında üretilen diğer bazı görüşler, aktif tutumu doğrudan teşvik edici içeriklere sahiptir. Bunlar arasında yer alan Fransis Fukuyama'nın tarihin sonu tezi ${ }^{9}$, Samuel Huntington'ın medeniyetler çatışması tezi, Robert Cooper'ın liberal emperyalizm yorumu ve egemenliğin kullanılmasını özgürlüklerin korunması şartına bağlayan çeşitli görüşler (Ikenburry, 2011: 247-249); liberal değerlere karşı çıkanların bir şekilde dönüştürülmesi ortak paydasında uzlaşmışlardır.

Liberal tezlerin hemen her zaman Amerikan dış politikasında bir karşılık bulduğu değerlendirilebilir. Wilson'a kadar bu karşılık belli örneklerle sınırlı iken, Wilson'un Kantçı barış anlayışından esinlenen dünya siyasetini dönüştürme vizyonu ile bu karşılık belirgin hale gelmiştir. Soğuk Savaş döneminde süpergüçler arasında nükleer savaş ihtimali, dış politikada liberal fikirlerin karşılık bulmasını sınırlandırdıysa da, Carter yönetiminin insan hakları ve Reagan yönetiminin demokrasi ve özgürlükler vurgusu ile birlikte liberal fikirlerin etkisi tekrar görünür hale gelmiştir.10 Soğuk Savaş sonrasında, Trump öncesi yönetimlerin dış politikalarında değerlerin hayata geçirilmesi için aktif tutum öneren fikirlerin ciddi karşılık bulduğu belirtilebilir. Çünkü bu yönetimler, aralarındaki derece farklılıklarına rağmen, 21. yüzyılda Amerikan hegemonyasının kuvvetleneceği fikrine sahip olmuşlar (Dunne, 2000: 25) ve uygulamada demokrasinin yayılması için zorlayıcı yöntemler kullanmaya az veya çok ilgi göstermişlerdir. W. Bush yönetimi zorlayıcı yöntemlerle

9 Fukuyama, demokrasinin zorla yayılmasını Amerikan siyasetine taşıyan neo-muhafazakar siyasi akımın üç temel teorisyeninden birisidir. Askeri yöntemlerin kullanılması konusunda neo-muhafazakarlar ile görüş ayrılığına düşünce, neo-muhafazakar akımdan uzaklaşmıştır. Ancak liberalizmin üstünlüğü için mücadele fikrinden vaz geçmemiştir.

10 Reagan yönetiminin demokrasinin yayılması siyasetine Kant ve liberal barıș anlayıșının etkisi için bkz. Søndergaard, 2019: 47-49. 
demokrasinin yayılmasını en uç noktaya taşımıștır (Thompson, 2010: 44-45; Bouchet, 2013: 43).

Demokrasinin zorlayıcı yöntemlerle yayılmasına desteğin artmasında neo-muhafazakarlık akımının ${ }^{11}$ rolü büyüktür. Reagan yönetiminde etkin olmaya başlayan neo-muhafazakarlık, Amerikan hegemonyası fikrini terk etmeksizin 1990'lı yıllarda demokrasi ve insan hakları söylemini benimsemiștir (McClelland, 2011: 530).12 Bu söylemi ile hem Cumhuriyetçileri hem de Demokratları müdahaleciliğe yönlendirmiştir. Clinton yönetiminde izleri görülen neo-muhafazakar etkisi W. Bush yönetiminde zirveye çıkmış, Obama yönetiminde önemsenecek ölçüde devam etmiştir.13 Ancak müdahaleciliği sadece neo-muhafazakar etkiye bağlamak doğru olmayabilir. Çünkü ABD'deki liberal siyasal akım içinde bir kesim (ayırt edici özellikleri, dünya barışı için, yani seküler bir duruşla, ulus-inşası ve rejim değişikliği politikalarını savunmalarıdır) arasinda da müdahaleci fikirler kuvvetlidir (Hoffmann, 1995: 171). Bu iki siyasal çizgi, liberal değerleri reddedenlere karşı güç kullanılması konusunda uzlaştıkları örneklerde ${ }^{14}$ müdahalecilik en üst seviyesine çıkmıștır. Örneğin, 2003 yılında Irak'ın işgaline Cumhuriyetçiler yanı sıra Hillary Clinton ve Joe Biden gibi çok sayıda Demokrat, diğer gerekçelere ilaveten otoriterliğe karşı çıkmak için destek vermiştir (Chollet \& Lindberg, 2007: 5).

Amerikan istisnacılığı anlayıșı da değerler adına aktif tutuma dayanak sağlamaktadır. Çünkü Amerikan toplumunun kendisini demokrasinin ve bireysel özgürlüklerin yayılması ve gerektiğinde savunulması misyonunu üstlenmiş 15 (yani erdemli davranan ${ }^{16}$ ) bir ulus olarak görmesine, Amerikan sistemlerinin

11 Burada radikal neo-muhafazakarlar kastedilmektedir (bu konuda bkz. Homolar-Riechmann, 2009: 187).

12 Neo-muhafazakarların liberalizmi doğru anlayıp anlamadıkları Amerikan dış politikasını çalışanlar arasında tartışmalı bir konudur. Kant ve John Stuart Mill gibi klasik liberal düşünürlerin barıș için demokrasinin gerekliliği konusundaki fikirlerinin zorlayıcı araçların kullanılmasını teşvik ettiği, dolayısıyla neo-muhafazakar politikaların liberal düşünce ile uyum içinde olduğu argümanı savunulduğu gibi (örneğin bkz. Singh, 2015: 100-103), neo-muhafazakarların demokrasi söylemini sadece araçsallaştırdığı da savunulmaktadır (örneğin bkz. Ryan, 2010; Ikenburry, 2011, 265-266).

13 W. Bush yönetiminin Savunma Bakanı Robert Gates'in Obama yönetiminde de bu görevini sürdürmesi gibi uygulamalar ve liberallerin değerler ve dış politika konusunda neomuhafazakarlar ile benzer fikirleri savunmaları (demokrasinin yayılması için aşırı güç kullanımı hariç), Obama döneminde neo-muhafazakar etkinin sürmesinde rol oynamıștır (Homolar-Riechmann, 2009: 191-192).

14 Amerikan siyasal kültürü, farklı siyasal akımların uzlaşmasına açıktır. Hatta etkili bireyler, akımlar arasındaki etkileşimde önemli roller oynayabilmektedir. Tarihçi ve jeo-strateji uzmanı Rober Kagan, bir örnek olarak verilebilir. Neo-muhafazakarların temel dış politika fikirlerini üreten Yeni Amerikan Yüzyılı isimli düşünce kuruluşunun kurucuları arasında yer alan Kagan, başkan adaylarından Hillary Clinton (Demokrat) ve John McCain'e (Cumhuriyetçi) danışmanlık hizmeti sağlamıştır (Gherasim, 2017: 67).

15 Dini referanslara sahip siyasi akımlar misyonun Tanrı tarafından verildiği iddiasıyla, seküler akımlar ise insanlığın ortak yararı için istisnacılığı savunmuştur.

16 İstisnacılık ile ABD’nin gücünü erdemli kullandığı (veya kullanması gerektiği) düșüncesi arasındaki bağlantı hakkında kapsamlı analiz için bkz. Kane, 2003: 772-800. 
istisnai oluşunun diğer toplumlar tarafından kabul edilmesini istemesine ve yöneticilerden de diș politikayı Amerikan misyonuna uygun yürütmelerini talep etmesine (Forsythe; 1995: 111, 119) yol açmıştır. Amerikalı yöneticiler de istisnacılık anlayışına bağlıklarını güçlü ifadelerle belirtmişlerdir. Örneğin, Wilson ve W. Bush, ABD’nin “küresel kötülük ile savașması için Tanrı tarafından seçilen ulus" olma niteliğine vurgu yapmiştır (Glaser, 2006: 256). Clinton yönetiminde Dışişleri Bakanlığı görevini üstlenen Madeleine Olbright, ABD’yi "vazgeçilmez [liderlik etmesi gereken] ulus" olarak tanımlamıştır. Clinton ve Obama da bu tanımlamayı desteklemiştir (Starobin: 2019; Bouchet, 2013: 38). Amerikan istisnacılığı hakkında Michael Dunne (2000: 25-26, 40), istisnacılığın, "en azından Devrimden itibaren Amerikan kültürünün bir parçası" olduğu görüşündedir. Ona göre "rakip bir güç, üçüncü binyılın hegemon gücüne meydan okuyana kadar" ABD kendisini istisnai bir ulus olarak görmeye devam edecektir.

\section{Sonuç}

$\mathrm{Bu}$ makalede incelenen beș özellik, birbirini desteklemek veya tamamlamak suretiyle liberal değerleri elde etme hedefinin Amerikan dış politikasında bir süreklilik unsuru olmasına katkıda bulunmaktadır. Bu katkıyı topluca değerlendirdiğimizde aşağıdaki kanaatlere ulaşmak mümkündür.

Birincisi, Amerikan karar vericileri, dış politikası vasıtasıyla demokrasinin yayılması ve hak ve özgürlüklerin savunulması çabasının hem Amerikan yararına hem de insanlık yararına bir çaba olduğunu düşünmüşlerdir. İnsanlık yararına hareket ediyor olmak, Amerikan karar vericilere bir vizyon sağlamış ve motivasyon kaynağı olmuştur. İkincisi, demokrasinin yayılması ve hak ve özgürlüklerin savunulmasını amaçlayan hedeflerin Amerikan dış politikasında yer alması, Amerikan çıkarının genel çıkar içinde aramasını gerektirmemiş; ABD, izlediği değerlere dayanan siyaset ile genel çıkardan bağımsız olarak güncel çıkarlarını elde edilebilmiştir. Ayrıca ABD, güncel çıkarlarını genel çıkar ile uyumlaştırma arayışı içinde de olmamıştır. Farklı yönetimler, çoğu zaman değer-dışı faktörlerin etkisiyle değerleri elde etmeye yönelik farklı stratejiler izlemiştir veya değerlere dayalı siyasaların istenmeyen sonuçları karşısında siyaset değişikliğine gitmiştir. Üçüncüsü, liberalizm ideolojisi ve Amerikan istisnacılığı, dış politika vasıtasıyla değerlerin elde edilmesi için aksiyoner davranmayı (kimi zaman zorlayıcı önlemlere başvurulmasını da içermiștir) özendiren bir işlev görmüştür.

Sonuç olarak, liberal değerlerin yayılması ve korunması, Amerikan dış politikasının kalıcı bir unsuru olmuştur. Bu sayede ABD, kendisini moral ilkelere göre davranan bir ulus olarak sunabilmiştir. Aynı zamanda ABD, değerleri yayma ve koruma misyonunu kendi şartlarını esas alarak ve kendine özgü bir tarzda yürütmeyi sürdürebilmiştir. Amerikan iç siyasetinde ve dünya siyasetinde ABD’yi daha farklı davranmaya zorlayacak köklü değişiklikler meydana gelmediği müddetçe, ABD’nin kendine özgü değerlere dayanan dış politika anlayışında ve pratiğinde kapsamlı değişiklikler yapmayacağı beklenebilir. 


\section{Kaynakça}

Ahsan, I. B. (2019). Why did the United States Invade Iraq in 2003? Security Studies, 28(2), 250-285. DOI: 10.1080/09636412.2019.1551567

Bouchet, N. (2013). The Democracy Tradition in U.S. foreign Policy and the Obama Presidency. International Affairs, 89(1), 31-51.

Brancati, D. (2014). The Determinants of U.S. Public Opinion Towards Democracy Promotion. Political Behavior, 36(4), 705-730. DOI: 10.1007/s11109-013-9256-y

Chollet, D. \& Lindberg, T. (2007). A Moral Core for U.S. Foreign Policy. Policy Review, 146, 3-23.

Congressional Research Service. (2020). U.S. Role in the World: Background and Issues for Congress (R44891). https://sgp.fas.org/crs/row/R44891.pdf [15.05.2020].

Dunne, M. (2000). U.S. Foreign Relations in The Twentieth Century: From World Power To Global Hegemony. International Affairs, 76(1), 25-40.

Forsythe, D. P. (1995). Human Rights and U.S. Foreign Policy: Two Levels, Two Worlds. Political Studies, XLIII, 111-130.

Gherasim, G. C. (2017). Ideological Realpolitik, Euroscepticism and American Exceptionalism In Robert Kagan. Romanian Review of Political Sciences and International Relations, 14(1), 66-80.

Glaser, D. (2006). Does Hypocrisy Matter? The Case of U.S. Foreign Policy. Review of International Studies, 32(2), 251-268.

Gourevitch, A. (2007). Neo-Wilsonianism: The limits of American Ethical Foreign Policy. Rethinking Ethical Foreign Policy (25-49). London and New York: Routledge.

Henriksen, T. H. (2017). Cycles in U.S. Foreign Policy since the Cold War. Palgrave Macmillan.

Hoffmann, S. (1995). The Crisis of Liberal Internationalism. Foreign Policy, 98, 159177.

Homolar-Riechmann, A. (2009). The Moral Purpose of U.S. Power: Neoconservatism in The Age of Obama. Contemporary Politics, 15(2), 179-196. DOI:10.1080/13569770902858111

Huber, D. (2015). Democracy Promotion and Foreign Policy. Palgrave Macmillan.

Ikenberry G. J. (2011). Liberal Leviathan: The Origins, Crisis, and Transformation of the American World Order. Princeton \& Oxford: Princeton University Press.

Kane, J. (2003). American Values or Human Rights? U.S. Foreign Policy and the Fractured Myth of Virtuous Power. Presidential Studies Quarterly 33(4), 772-800.

Lasher, K. J. \& Rinehart, C. S. (2016). The Shadowboxer: The Obama Administration and Foreign Policy Grand Strategy, Politics \& Policy, 44(5), 850-888. 
McClelland, M. J. L. (2011). Exporting Virtue: Neoconservatism, Democracy Promotion and the End of History. The International Journal of Human Rights, 15(4), 520-531.

McFaul, M. (2004). Democracy Promotion as a World Value. The Washington Quarterly, 28(1), 147-163.

Obama, B. (2007). Renewing American Leadership. Foreign Affairs, 86(4), 2-16.

Pee, R.\& Schmidli, W. M. (2019a). Introduction. The Reagan Administration, the Cold War, and the Transition to Democracy Promotion, (1-28). Palgrave Macmillan.

Pee, R.\& Schmidli, W. M. (2019b). Conclusion. The Reagan Administration, the Cold War, and the Transition to Democracy Promotion, (277-301). Palgrave Macmillan.

Perkins, B. (1994). Interests, Values, and the Prism: The Sources of American Foreign Policy. Journal of the Early Republic, Winter, 14(4), 458-466.

Ruggie, J. G. (1997). The Past as Prologue? International Security, 21(4), 89-125.

Ryan, M. (2010). "Exporting Democracy"? Neoconservatism and the Limits of Military Intervention, 1989-2008. Diplomacy \& Statecraft, 21(3), 491-515.

Singh, R. (2015). 'Defensive Liberal Wars': The Global War on Terror and the Return of Illiberalism in American Foreign Policy. Revista de Sociologia e Política, 23(53), 99-120.

Smith, T. (1994). America's Mission: The United States and the Worldwide Struggle for Democracy in the Twentieth Century. Princeton University Press. Princeton, NJ.

Søndergaard, R. S. (2019). "A Positive Track of Human Rights Policy": Elliott Abrams, the Human Rights Bureau, and the Conceptualization of Democracy Promotion, 1981-1984. The Reagan Administration, the Cold War, and the Transition to Democracy Promotion, (31-50). Palgrave Macmillan.

Starobin, P. (2019). Indispensable Nation Nostalgia. American Affairs Journal, https://americanaffairsjournal.org/2019/08/indispensable-nation-nostalgia/ [20.06.2021].

The House of Representatives. (2018). Democracy Promotion in A Challenging World. Hearing Before the Committee On Foreign Affairs House of Representatives, June 14, 2018. https://www.govinfo.gov/content/pkg/CHRG-115hhrg30423/pdf/CHRG115hhrg30423.pdf [13.01.2021].

Thompson, J. A. (2010). Wilsonianism: the Dynamics of a Conflicted Concept. International Affairs, 86(1), 27-48.

Walker, S. (2019). American Foreign Policy and Forced Regime Change Since World War II. Palgrave-Macmillan. 
